\title{
The network function of
}

\section{civil society organizations in times of the COVID-19 pandemic - or how engagement as a practice of solidarity becomes market-relevant}

\author{
Janine Kuhnt (Janine.kuhnt@uni-jena.de) \\ Friedrich-Schiller-Universität Jena, Germany
}

\begin{abstract}
When political actors mandate the use of protective masks or makeshift masks in public, and these products are scarce on the market, local engagement-promoting organizations arrange their procurement independently. Taking on the responsibility of serving the local need for makeshift masks is based on the engagement of the citizens: as resource contributors and sewers they follow the call of community foundations, for example, to produce masks as a way of practicing solidarity with local actors. Through the 'netnographic' access to and a network-analytical perspective on self-presentations of community foundations, the present article deals with the question of how these foundations organize the production and provision of the product 'makeshift mask'. Conclusions are (1) that the network function of the local organizations of civil society with regard to the operation and fulfillment of the need for makeshift masks is central and (2) that voluntary- and solidaritybased engagement gains market-relevance through the production of a 'valuable' product. At the same time, however, solidarity as a basis for action is fragile because it arises from the active engagement of citizens, which also rests on the expectations of reciprocity.
\end{abstract}

Keywords: community foundations, makeshift masks, network function, solidarity, COVID19 pandemic

\section{Introduction}

Local civil society organizations (synonymous with "third sector organizations") that promote engagement are not only multifunctional because they provide services, represent interests, lobby and perform a socially integrative function as member organizations (Zimmer \& Priller, 2007, 20-22; Backhaus-Maul \& Hörnlein, 2014, 117): in the face of social challenges and acute need, they are locally networked 'multi-talents' that gain marketrelevance by producing and distributing a product with high demand, as will be shown in the following article. As political decision-makers, who are aware of the scarcity of the resource 'protective mask' and its high market demand, introduce the mandate of wearing makeshift masks in their municipalities, the question of the availability of this resource from the perspective of individual citizens - remains an unresolved issue. Organized civil society actors react to the existing need and increased demand for makeshift masks, on 
the one hand, and to the introduction of the obligation to wear a mask in defined public spaces, on the other hand, by self-organizing the production of the very popular masks or having them produced by engaged citizens.

The term 'organized civil society' refers to one of three dimensions of civil society that Kocka (2003) introduced into the German discourse: the descriptive-analytical dimension. If the organized actors of civil society are taken into account, a term of civil society is used that relates to "the self-organized, dynamic, tension-filled public spaces of associations, networks, movements and organizations 'between' the state, economy and privacy" (ibid., 32; emphasis in original).

"Associated with such a perspective is also a high degree of appreciation for this sector and its associations, as it seems most likely to embody what is associated with the utopia of a largely informal society and a certain organized equilibrium in the sense of a pluralism of different and often conflicting, but in principle unites interests that are equally valid." (Evers, 2020, 11)

At the same time, this positive form of organized civil society does not simply exist: A number of preconditions are required for the development of a free and relatively peaceful appearance of the organized civil society (ibid.). In addition to the freedom to organize yourself as a citizen in associations, the available resources of the individual (access to associations and material resources, availability of time, etc.) and a differentiated infrastructure of organizations that promote engagement can be understood as prerequisites. Besides the personal and organized opportunities to engage locally, another prerequisite is addressed that can also be considered an expression of civil society: the habitual dimension that is action-oriented and emphasizes behaviors such as nonviolence, compromise orientation and solidarity (Kocka, 2003, 33). The free and relatively peaceful side of civil society must therefore be actively and repeatedly recreated by engaged people in organized contexts. This also addresses the third - the normative - dimension of civil society, which encompasses certain societal foundations of coexistence, such as cross-sectoral and continuous discussion and understanding of what constitutes a 'good society'. For Kocka $(2003,32)$, the normative dimension of civil society is linked to the fact that it can be understood "as the core of a design or project with still utopian features". With regard to the utopian features, Evers $(2020,17)$ states: "What constitutes the civility of a 'good society' is never determined once and for all".

If the three dimensions of civil society are considered together, it can be stated that (1) engagement most often takes place in formally organized associations (Simonson \& Vogel $2017,524)$. (2) From the point of view of those who are interesting in starting a voluntary activity, solidarity is seen as an important value that motivates them, to start it (Huxhold \& Müller, 2017, 496). The data from the last nationwide volunteer survey in Germany (from 2014), in which citizens aged 14 and over were asked about volunteering, make it clear, "... that people for whom solidarity is important volunteer proportionally more often (46.8 percent) than people who find this value less important (39.5 percent)" (Huxhold \& Müller, 2017, 490). (3) The organizations of civil society can be viewed as institutionalized contexts in which citizens can get involved and exchange ideas about what constitutes, or should constitute, a civil - in the sense of good and/or solidaric - society. After all, the third most common reason to begin engagement activity (after "having fun" and "getting together with other people") is "helping to shape society," which 57.2 percent of the respondents in the volunteer survey fully agree with (Müller et al., 2017, 427).

With regard to the organized contexts in which engagement is promoted and takes place, from a descriptive-analytical point of view it can be noted that: 
"Engagement in Germany is embedded in a dense network of public and non-profit organizations that promote it and provide opportunities for volunteers to participate locally. Both organized civil society itself and the fields of action in which citizens engage locally are heterogeneous and multi-faceted." (Kuhnt, 2019, 157)

The systematic survey and analysis of the modes of engagement promotion through various actors in organized civil society and their political-administrative framework for promoting engagement is in its initial stages and there are still research desiderata (Kuhnt, 2018; Kuhnt, 2019; Backhaus-Maul et al., 2015, 610 f.). While Backhaus-Maul et al. (2015, 456) developed a typology for the ideas of engagement and its promotion through actors in welfare organizations, there are very few comparable current analyses and findings in the German discourse concerning how engagement in other organizations is encouraged and integrated into the provision of services. In the German social science discourse, there are only compressed case studies on selected actors of the local engagement-promoting infrastructure (Wolf \& Zimmer, 2012), comparatively older findings for volunteer agencies only (Speck et al., 2012), and rather descriptive representations of the local engagementpromoting infrastructure (Jakob, 2010).

What the organizations that Backhaus-Maul et al. (2015) have examined have in common is "that they face the challenge of recruiting, promoting and managing engagement depending on their professional self-image" (Kuhnt, 2018, 551 f.). In general, non-profit organizations in the German welfare state are included in the provision of social services on the basis of the principle of subsidiarity and in context of a welfare-mix. The concept of a "welfare-mix" or "welfare pluralism" describes the division of tasks and responsibilities for welfare production between the four sectors: government, market, informal (or private) and intermediate (or organized civil society) sectors (Evers \& Olk 1996, 16 and 23). As part of this division of responsibility for the production of public goods between these sectors, the public sector assumes a "guarantee function". The guarantee function of the public sector includes the provision of suitable regulatory structures, while the implementation and financial responsibility for the provision of public goods and services are transferred to the private and the intermediate sector:

"Everything can be relocated, privatized and delegated, the state only has to guarantee that there are corresponding goods and services for all citizens in a certain quality and quantity. The state does not have to act as the producer of these goods and services itself; that can be left to other actors." (Nullmeier, 2011, 292)

The 'withdrawal' of the state from its guarantee function is based on the guiding principles of an activating welfare state:

"The corresponding buzzwords are: service activation instead of service reduction, dialogue instead of decree, co-production instead of negotiation, self-organization instead of sovereign welfare or a new division of responsibility instead of transferring responsibility." (Braun et al., 2013, 49)

In the context of the division of responsibility and the cooperation between public actors and those of the organized civil society for the provision of public goods, Germany has traditionally been regarded as a "prime example of a welfare state with a neo-corporatist character" (Freise \& Zimmer, 2019, 11). Particularly welfare organizations are assigned a privileged position in the neo-corporatist welfare arrangement: As corporatist actors they are included in the political decision-making and legislative process, recognized as nonprofit (in the sense of benefit to the public) and privileged under tax laws (Backhaus-Maul et al., 2015, 36). From the perspective of the traditionally organized contexts in which engagement is promoted - welfare organizations - engagement is seen as constitutive and it serves as a crucial political basis for legitimation in corporatist negotiations with the 
welfare state (ibid., 14 and 581). However, Backhaus-Maul $(2019,96)$ notes a change in the neo-corporatist welfare arrangement for the organizations within the voluntary welfare as an institution: According to him/this change, individual organizations in particular experience appreciation and gain importance, while the institution itself is rather weakened in the context of changing political economic conditions. In addition to the strengthening of individual organizations within the voluntary welfare sector (Backhaus-Maul primarily refers to federal and state policies), other organized civil society actors - as comparatively 'new players' in the organizational field of engagement-promoting actors - are gaining in importance at the local level.

Especially at the local level, actors of the organized civil society are viewed as important cooperation partners for the local government (Freise \& Zimmer, 2019, 12). Compared to the traditional welfare organizations, Community Foundations (CF) can be considered 'newer players' that are increasingly appearing at the local level (Kuhnt, 2020, 328). While for welfare organizations engagement is considered to be constitutive and a basis for legitimation in negotiations with public actors, for CFs, engagement is no less constitutive and its promotion is an essential, if not the central organizational purpose (ibid., 323). With a view to the self-conception and purpose of CFs it becomes clear that when they are operationally active, they respond to local needs in project form. It is therefore not surprising that CFs are especially understood as "money collectors" (Wolf \& Zimmer, 2012, 148) and cooperation partners for other local actors (ibid., 149). With regard to the question of which local needs should be served in project form by CFs, one thesis is that it is primarily the actors who can be activated as providers of resources such as time, knowledge and money who decide on the urgency of the needs to be processed (Kuhnt, 2020, 331). And thus, about the eligibility of projects. There is a risk that weak interests may potentially be disregarded.

When political decision-makers introduced the obligation to wear a mask in defined public spaces, but from the perspective of the citizens its procurement was unclear, it could be observed that CFs took on their function as collectors of resources at the local level and started appeals for donations. Based on this observation, in the following article the question is examined regarding how community foundations, as local actors in organized civil society, manage the production and provision of makeshift masks and in this context take responsibility for the procurement of a good of public interest.

In order to pursue the leading question, three CFs in Germany were initially selected through a netnographic access to the field, as will be explained in chapter two. The selected CFs ('cases' in chapter three) will be analyzed with regard to their online calls for producing and donating masks and materials. After the description of the cases, in regard to the calls presented online, in which it becomes clear that the CFs serve the local need for makeshift masks in network structures, an ego-centered network analysis will be carried out to evaluate the different modes in which they take on local responsibility for mask production and provision (chapter 4). Since (ego-centered) network analysis is not a singular, stringent method (Clemens, 2016, 46) and there is no one 'proven' procedure for the evaluation and analysis of (ego-centered) networks based on qualitative data, the data considered here are evaluated inspired by qualitative content analysis that is focused on empirical typification (Kuckartz, 2016, 153). In the conclusion (chapter 5) it will become clear that in times when political actors at the local level are urging citizens to wear makeshift masks due to a pandemic, but the availability of the masks is not ensured, the CFs show that they are capable of doing more than just mobilizing resources from active citizens. They have proven to be reliable actors who take responsibility for the production and distribution of a publicly relevant good when the political decision-makers have outsourced the responsibility for its procurement to the citizens themselves. In this context, CFs act as important cooperation partners for actors of the local government and for those 
of the civil society, but also become market-relevant actors through the self-organization of the production of a product with high demand, regardless of their non-profit nature. And finally, a central thesis is that CFs in particular can achieve market-relevance because they take on a local network function, which ultimately enables them to generate resources and distribute products.

\section{Case selection based on a netnographic approach to the field}

The data that forms the basis of the analysis in this article includes publicly accessible, online self-presentations of three selected CFs in Germany, meaning the public calls that the CFs have communicated online to generate material donations and donations of makeshift masks from engaged citizens. The selection of, and access to, the qualitative data material that is considered relevant for the processing of the leading question is made from a netnographic perspective. The term netnography is usually used synonymously for online ethnography (Geimer, 2018, 176).

"Netnography is based on the observation of text documents of the user generated content. [...] As an online adaptation of ethnography, netnography is a primarily qualitative research method based on the cultural contextualization of online data." (Janowitz, 2009, 4-5)

In this sense, in this article the actors in CFs are considered to be those who use the internet to post and distribute content. From a methodical-methodological perspective, netnography is a type of access to the field and finally to the research subject of interest through (ethnographic) observation of activities that primarily take place online. With regard to the fusion of everyday life with the Internet, $\operatorname{Geimer}(2018,176)$ states that, on the one hand, there are no fixed boundaries between offline and online and, on the other hand, this fusion opens up different degrees of opportunities for people to participate and, accordingly, different opportunities of (ethnographic) observation as well. In the course of a netnographic access to the field, there is no need to spend a long time in it, as is common in traditional ethnographic studies (Geimer, 2018, 177). One reason for this is that the observed communication processes are already 'logged' by the researched subjects themselves, presented in text or pictorial form and are therefore relatively quickly accessible to researchers. While in ethnographic discourse the text production by researchers is viewed as a method of gaining knowledge (Przyborski \& Wohlrab-Sahr, 2014, 400), the netnographic access to knowledge is similar to a treasure hunt for communication material that has already been generated by the researched themselves. Although in complex netnographic studies it is usually provided that the researchers address the field and the research subject both online and offline in order to link the online observations back to offline observations (Bozdağ, 2018, 139), here only an online perspective is taken. There is no extensive access to the field, as the data collection or the observation of the forms of representation and communication in the self-presentations of the CFs takes place exclusively through an online focus. This contribution gives situational and temporary insights into the field, in that the research period is limited to what can be considered part of the beginning of the COVID-19 pandemic in Germany, from May 1 through May 12, 2020, and generating findings that 'invite' the academic community to conduct further in-depth offline research. The self-image of the respective CFs, which is publicly presented online, depicts the ideas of how they want to take responsibility by producing and distributing masks, how they address third parties (i.e., citizens and actors of organized civil society) and which structures for assuming responsibility they describe. The online focus doesn't allow the researcher to experience the action that takes place offline, the ways in which the addressees follow the appeal of the CFs, the motives for which they follow it, or the forms of recognition they receive for their engagement, for example. Although the analysis 
of the actors' online communication content is a specific cutout of an online reality created by them, it should be emphasized that - because of the online focus - this (also) enables an analysis of that reality to see how the actors want to be perceived and how their target group potentially sees them and reacts (or not) to their communication. Due to the chosen online focus with the added situational and temporal limitations, only the organizations' "facade" pages (Kühl, 2011, 89) are accessible. The other pages presenting organizational practice ("machine" and "game" pages; ibid.) could be the subject of a subsequent analysis. However, it must be taken into account that the facade pages help organizations gain legitimacy within their organizational environment (Walgenbach \& Meyer, 2008, 64), which is relevant in order to be effective, as the final part of this article will show. To put it in the words of Kühl (2011, 89; emphasis in the original):

"With the image of organizations as 'facades, ' 'stages' or 'theatre', observers emphasize that it is important for organizations to mobilize support in their environment with a smooth external image."

In order to analyze the mobilization potential of CFs, the online focus concentrates on the call of the organizations on their facade pages, through which engaged citizens should be mobilized or activated. The criteria for the selection of the analyzed cases are the following: (1) There is an online call for engagement in the form of the production of makeshift masks, and (2) the content of the call is made publicly available online. The CFs in Braunschweig (Lower Saxony), Gutersloh (North Rhine-Westphalia) and Jena (Thuringia) serve as exemplary cases that meet these criteria.

\section{The cases in comparison}

The Community Foundation Braunschweig initiated the "mask project" in cooperation with "Sandpit of the TU Braunschweig", a university-based project for the voluntary engagement of those affiliated with the university TU Braunschweig (Technische Universität Braunschweig, 2020) and the local fabric shop "SchickLiesel." Goal of the project is to distribute makeshift masks for "medical, nursing and social institutions" (Bürgerstiftung Braunschweig, 2020a) produced by engaged citizens and supplied to the CF. The project itself does not have the capacity to organize the provision of masks produced by volunteer sewers to citizens; the foundation does, however, refer citizens to local (commercial) points of sale (ibid.). After the CF reported having distributed 13,000 masks to 160 institutions in Braunschweig - from medical facilities to schools - its website announced on May 7, 2020 that the project was ending due to declining requests from organizations (Bürgerstiftung Braunschweig, 2020b). It can therefore be assumed that the needs in the previously defined fields of action (medical, nursing, social) had been met. 
Figure 1: The Community Foundation Braunschweig informs citizens about local points of sale for makeshift masks

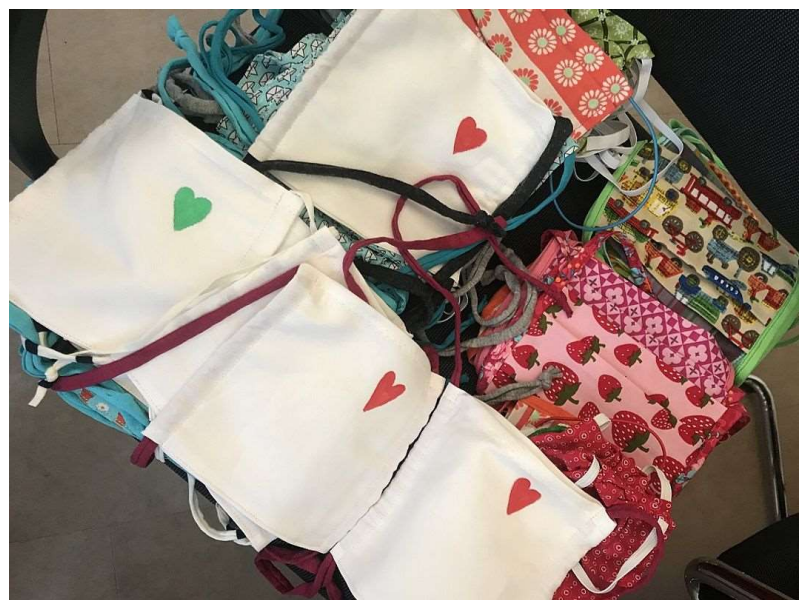

Image in the representation of the online call; Source: Bürgerstiftung Braunschweig (2020c).

As part of the "Mask on" campaign, the Community Foundation Gutersloh voluntarily calls on engaged sewers to sew makeshift masks and donate them to the CF to be sent to "midwives, visiting nursing services, medical and physical therapy practices, social institutions and private initiatives" (Bürgerstiftung Gütersloh, 2020) after prior registration and according to availability (ibid.). The masks are passed on to local care services, residential groups, retirement homes, the German Red Cross or to schools in Gutersloh, for example (dein-guetersloh.de, 2020). Private citizens who need makeshift masks are explicitly excluded: they are primarily addressed as engaged sewers and/or citizens who wish to donate resources (i.e., sewing materials). In the context of the call to action, the CF sees itself as a "support platform" (Bürgerstiftung Gütersloh, 2020) that "brought willing donors of boil-proof, breathable fabric, bias or elastic, [...] and engaged producers together." (ibid.).

Figure 2: The Community Foundation Gutersloh calls on engaged sewers to produce masks

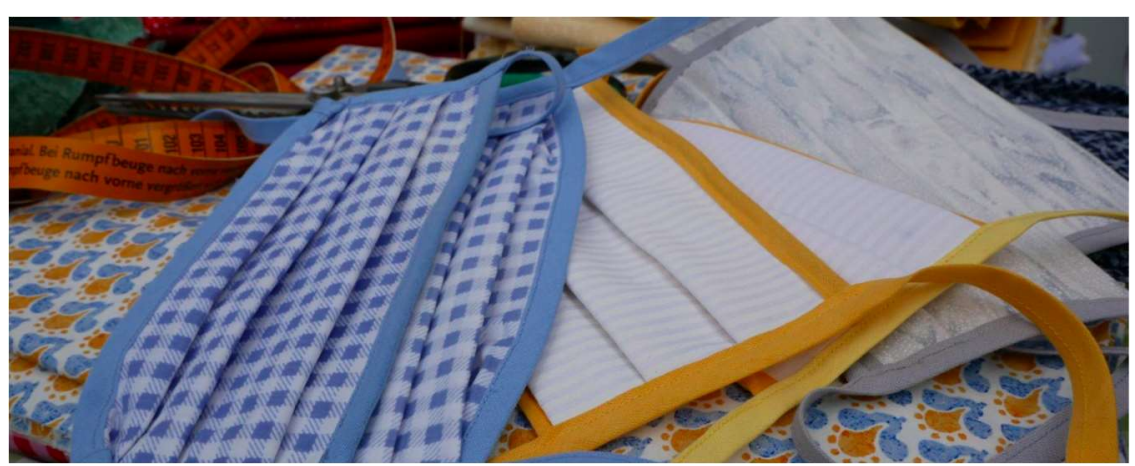

Image in the representation of the online call; Source: Bürgerstiftung Gütersloh (2020).

On its homepage (Bürgerstiftung Jena 2020), the Community Foundation Jena supports the municipality's appeal "citizens sewing for citizens" by calling on engaged citizens of Jena to sew makeshift masks. The homemade masks can then either be donated to the CF or to other "distribution points in every district" (ibid.). After being donated to the "distribution points", the makeshift masks are "laundered for the first time and then distributed to organizations in need" (ibid.). In addition to organizations that need makeshift masks, individuals can also receive up to two makeshift masks from the distributing points for personal use. Distribution points are provided by seven organized civil society actors (e.g., a meeting point of the Workers' Welfare Association 'AWO', an institution of the Catholic Relief Services Caritas, and the local Christian social service institution Diakonie) as well as 
the district mayors' offices in the surrounding towns. It is interesting that the CF presents itself as the center of the coordination of the masks, while the welfare organizations that are comparatively more established in Germany are correctly described as 'teammates' (distribution points) and not as centers of coordination themselves, as they rely on the CFs for their mask supply. The CF published a list of all the names and addresses of these locations on their homepage. One distribution point was noted to also distribute masks to personal mailboxes upon request (ibid.).

Figure 3: The Community Foundation Jena informs the public about the city's appeal "citizens sewing for citizens"

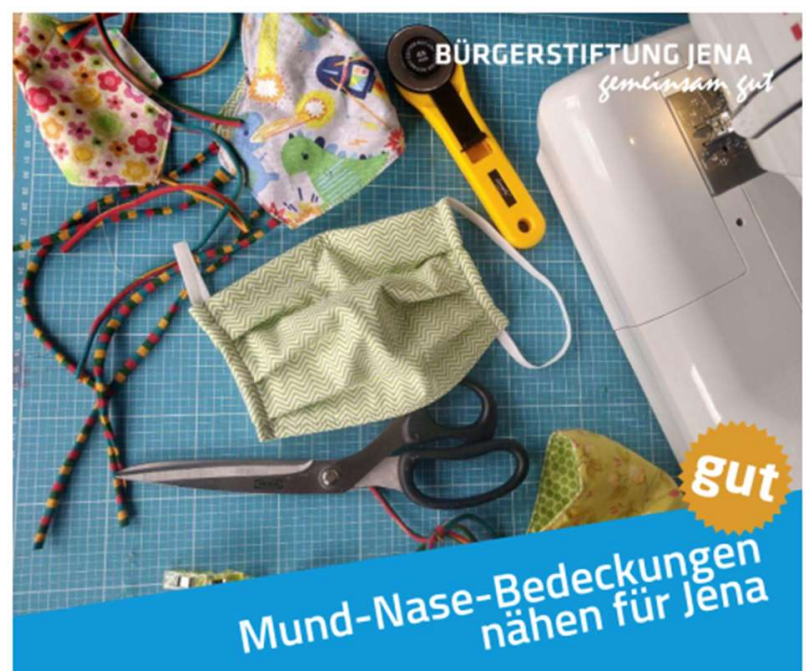

Image in the representation of the online call; Source: Bürgerstiftung Jena (2020).

The CFs' activities as communicated online make it clear that they act as reliable, locally organized actors with regard to offering solutions to pressing problems that are not adequately dealt with by neither the state nor the market. Furthermore, they seem to be successful: in the case of Braunschweig, the declining number of requests for masks by the organizations suggests that the demand for masks has been met (in specific organizations and fields of action) through the extensive engagement of mobilized sewers.

Regarding the self-image of all of the CFs as presented on their homepages, it is apparent that they want to be seen as cooperation partners, support platforms and coordinators. It is interesting that in two of the CFs under consideration, the need for the (scarce) resource makeshift mask is primarily assigned to organizations in defined fields of action, and a distribution of the product is not intended to supply individual private citizens with makeshift masks. The self-presentation of CF Jena, which presents itself online as a coordinator between the municipality's call for the production and donation of makeshift masks and their delivery to distribution points, deviates from that of the others. In Jena, citizens are also addressed beyond their capacity as sewers and people who donate material alone: they are also addressed as citizens with their own needs for masks. In this respect, the CF Jena differs from the other foundations considered.

In times of the COVID-19 pandemic, community engagement shows itself as a mode of responsibility for the local community on the part of citizens themselves. In organized forms, citizens practice solidarity by donating and bundling resources to meet local needs that cannot be adequately met otherwise (by the state or by the market):

"This particularly reflects the innovative function of engagement, which willfully and locally shapes fields of action either in addition to or compensating for professional practice." (Kuhnt, 2019, 165) 
The municipalities act as a kind of director, delegating the procurement of masks to citizens and civil society organizations because they cannot do it themselves; in their capacity as directors, they call on citizens to assume responsibility and organize themselves:

"However, since there is currently a shortage of commercially available cloth face masks, it is recommended that people sew masks themselves or have one sewn for them. Dense woven cotton can be used for this, corresponding sewing instructions can be found here, for example: ..." (Stadt Jena, 2020).

The perception of local political decision-makers reflects the functional and action logic of the state that is based on hierarchical structures and with a mandate to instruct; from a party-political perspective, this logic is "focused on the acquisition and exercise of state power" (Evers, 2020, 10). Although the obligation to wear a makeshift mask in public spaces is justified (the political decision and in this respect the exercise of power can be justified as a protective measure and risk reduction of virus spread), the delegation of responsibility for its procurement excludes citizens who are not able to adequately follow the call to self-organize and meet their needs for masks. Instead, these people use ill-fitting pieces of cloth to cover their faces. It could be argued that they could still buy makeshift masks. For market economy providers who switch their production of other textile goods to makeshift masks, this transition may be a lucrative company model because they can set corresponding prices for the product. Based on the functional and action logic of the market economy sector, it is apparent that the purchase of makeshift masks primarily depends on the purchasing power of citizens who need a mask, on the one hand, and on the availability of that resource on the market, on the other. Ultimately, the market sector aims to serve consumer demand via a price-mediated exchange (money for product) in order to maximize profits for providers. Depending on the provider, material and processing of the masks, the price of makeshift masks varies between four and 20 euros (Schnabel, 2020). It should also be taken into account that the purchase of several masks appears to be sensible and necessary if people want to follow the hygiene guidelines specified by the Robert Koch-Institut (e.g., changing the mask once it becomes damp) (Robert Koch-Institut, 2020). Citizens who are willing to wear makeshift masks in public but are not able to pay market prices are referred to the activated organized civil society (i.e., CFs) that shows solidarity with them by helping them meet their needs. In the context of welfare state research, solidarity and reciprocity are discussed as "an obligation to mutual support" (Zimmer, 2019, 28); Zimmer also states that it has not yet been a central topic of welfare state research "... to what extent civil society contributes to anchoring the welfare state in society and making welfare society possible" (ibid.). This shows the strength, and at the same time the fragility, of civil society and their organized contexts: Neither hierarchy nor price-mediated market exchange control and coordinate the organizations of civil society, but rather reciprocal forms of action control are constitutive for them; these forms are based on solidarity, trust and mutual expectations (Backhaus-Maul \& Hörnlein, 2014, 117). Solidarity-reciprocal forms of action control and coordination are fragile insofar as they rely on the fact that the expectations of reciprocity are also met. The data from the volunteer survey show that motives for taking up a voluntary activity, from the perspective of those interested in volunteering, are both related to the common good and self-related: "having fun" is the most frequently mentioned motive of those engaged, other self-related motives include, for example, "acquiring qualifications" and "gaining reputation and influence" (Müller et al., 2017, 427). A thesis in this context is that engaged citizens (generally) also have expectations of their volunteer work and do not exclusively do it for altruistic reasons. What motives and expectations the engaged had in this specific context (i.e., who donated material and masks) is an independent research question that could be investigated in an offline mode in a follow-up to this article. Organizations whose self-image is 
based on solidarity depend on engaged citizens who contribute to it for their own gain and that of others, therefore helping the organizations gain legitimation and fulfill their organizational purpose. CFs obtain legitimacy primarily through the inflow of resources from engaged citizens (time, knowledge, money), through which they can fulfil their organizational purpose (or at least they succeed in telling credible stories, the success of which can be measured by the inflow of resources; Kuhnt, 2020, 331). Evers $(2020,10)$ states that, in contrast to the market economy sector, the civil society/third sector "is not primarily concerned with the production of goods and services and therefore not with organizations that are forced by market arrangements to generate a monetary gain". However, with regard to the community foundations' objective of supplying makeshift masks, the foundations become market-relevant actors regardless of their non-profit nature because they have goods that are on high demand. Engagement itself gains market relevance through the production of a 'valuable' product based on voluntary action and solidarity. What if you actually calculate approx. 12 euros per mask (as of April 28, 2020; see: Jahberg, 2020) for the 13,000 masks produced and donated in Braunschweig (Bürgerstiftung Braunschweig, 2020b), the near 1,800 masks made for the CF Gutersloh (Bürgerstiftung Gütersloh, 2020), and for the approximately 10,000 masks donated in Jena? The combined market value of these masks would be approximately 297,600 euros based on an average price of 12 euros per mask. Imagine the financial investment that the medical, nursing and social institutions would have to make if they had to pay the 'real' market value for the scarce good, or if volunteers expected monetary remuneration for their time and/or material resources. These numbers show how valuable this free and solidarity-based engagement of citizens really is, and how important it is for the continued work of the organizations as end users.

In their organized contexts, engaged people not only comply with the appeal of political decision-makers by taking the responsibility for the provision of makeshift masks, they also strengthen the value of solidarity by following the appeal for the benefit of third parties. The engaged citizens can also be ascribed a market relevance since they manufacture products that are on demand and donate them to distribution points free of charge. The assumption of responsibility for third parties essentially takes place in network structures, which are discussed in more detail below.

\section{Serving the needs in network structures}

In comparison to the condensed case descriptions, it becomes clear that the assumption of responsibility by engaged, sewing citizens and the division of responsibility by organized actors at the local level are arranged similarly to a network.

"A network is defined as a delimited set of nodes or elements and the set of so-called edges running between them." (Jansen, 1999, 52)

The CFs' online self-presentations enable an analysis of the CFs' ego-centered networks. In the context of the analysis, each CF is understood as an "ego" that maintains different relationships with other local actors, which the ego presents online from its own perspective. The ego-centered network analysis "represents minimal network analytical access to reality, insofar as data are only collected about individual focal actors, and not about groups or entire networks" (Jansen, 1999, 73). The individual focal actors (here: CFs) constitute the center of the network, from which the relationships to other actors within their network as presented online by the ego can be traced.

In the analysis of the ego-centered networks based on online communication material (here: the online calls of the CFs to donate material and produce makeshift masks), the focus is on the discursive construction of the object-related relationships. Only the CFs' (online-based) communication material that is considered 'relevant' to answering the 
main question of this contribution is included in the analysis. Communication material is considered relevant if it contains information about the network structures of ego in relation to other actors - named by ego - in the context of the call for sewing makeshift masks as presented online by ego. The material is also examined with regard to the relational meaning (Fuhse, 2018, 148; Clemens, 2016, 58) (i.e., with regard to the relationships between ego and the other actors mentioned). Since (ego-centered) network analysis is not a singular, stringent method (Clemens, 2016, 46), different - primarily quantitative - approaches can be found in the discourse regarding the analysis of relationship structures. While quantitative analyses of networks generally do not differ significantly from the general statistical methods used in social science (Fuhse, 2018, 122), different methodological approaches are chosen for the investigation and analysis of qualitative data (Hollstein, 2006, 23).

The choice of a suitable method for the analysis of the qualitative data is primarily made with regard to the respective appropriateness for the object under investigation. Accordingly, there is no such thing as one 'proven' procedure for the evaluation and analysis of (ego-centered) networks based on qualitative data. In the present exemplary consideration of network structures in CFs, the qualitative data is evaluated inspired by a qualitative content analysis, which focuses on empirical typification (Kuckartz, 2016, 153). The typification here is focused on the online self-presentations of the CF in the context of their calls for the assumption of responsibility for the production of makeshift masks. The content of the respective types is determined by using thematic categories, which are developed according to the qualitative material - that is, based on the online self-presentations of the CFs themselves. The thematic categories are (1) the self-images of the CFs; (2) the specific relationships to other local actors; and (3) how CFs address the actors mentioned. The qualitative content analysis focused on empirical typification is considered a suitable methodological approach since the thematic categories can act as 'nodes' in the graphic representation of the ego-centered networks. There are two different types of nodes: collective actors, such as the organizations or the distribution points, and addressed citizens. The nodes shown additionally contain the analyzed communication content (thematic categories). Albrecht $(2010,128)$ states that the different nodes can be regarded as one and the same without neglecting the differences in their attribute data, which the analysis accounts for. As a result, three types can be found empirically that are similar in terms of how the CFs relate to other local actors in order to serve the need for makeshift masks: (1) the cooperation partner; (2) the support platform; and (3) the coordinator. These are characteristically heterogeneous types (Kuckartz, 2016, 150) in that the mode of action the CFs present online differs according to which actors they are referring to: cooperation, (re)distributing resources and coordination.

From the perspective of the foundations as the ego of their network, the relationships to other local actors differ depending on the foundation's self-image and how they address other actors; it can be stated that the relationships are both one-sided and two-sided. The foundations' addressing is comparable in that organizations are addressed as consumers, and citizens as volunteers who act out of solidarity by supplying the organizations with resources and donating finished products. The addressing can also be contrasted because the CFs address engaged citizens differently: On the one hand, citizens are addressed as responsible for, and capable of, producing masks for themselves and others, donating material for their production or procuring masks themselves. On the other hand, citizens are addressed as people who cannot meet their needs themselves (by sewing or buying masks) but are dependent on third parties who show solidarity with them so that they can also follow the guidelines of the political actors to wear a mask in defined public spaces. 
The relations and addressing of the CFs presented as a cooperation partner, support platform and coordinator with reference to other network actors can be represented in a graph (figures 4-6):

(1) The analysis of the online self-presentation of the Community Foundation Braunschweig shows that it cooperates with two other local actors on a project basis (a fabric shop and the so-called "sandpit" of the university, which acts as a contact point for voluntary engaged members of the university). The relationships are reciprocal to the $\mathrm{CF}$ in that the actors initiated the mask project together. Citizens are mutually related to the CF in two ways: as resource providers (sewing material) so that the CF can deliver it to sewers, on the one hand, and as sewers who can donate finished products (makeshift masks) to the $\mathrm{CF}$, on the other. Citizens who have a need for manufactured products themselves are referred to points of sale by the CF because the CF itself only delivers the finished products to institutions and professional groups in defined fields of action. The relationship to the latter is mutual in that they have to actively contact the CF with a request in order to be able to receive the finished products (depending on availability).

Figure 4: The Community Foundation Braunschweig's ego-centered network

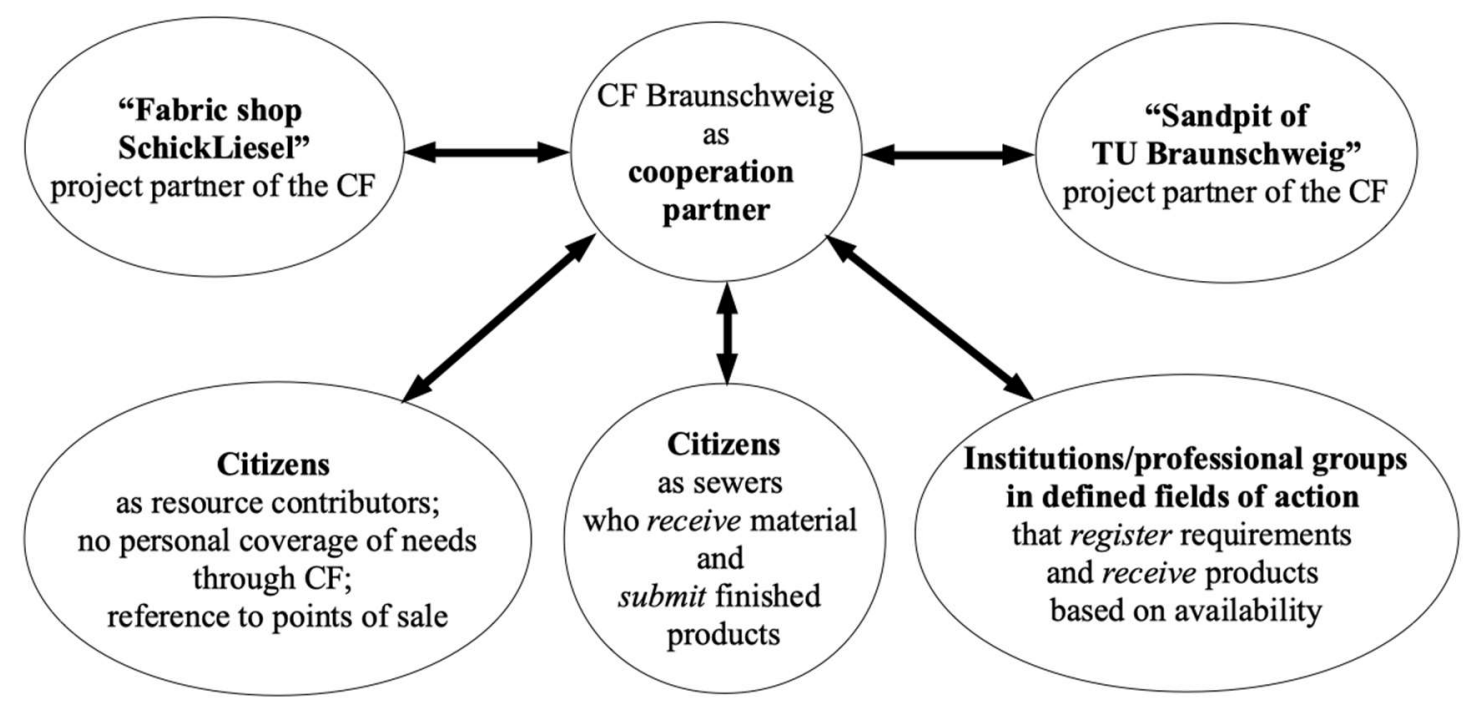

Source: own elaboration.

(2) The Community Foundation Gutersloh presents itself as a "support platform" (Bürgerstiftung Gütersloh, 2020). It is in this capacity that it accepts material donations from citizens and passes them on to other citizens who manufacture masks as volunteer sewers - mutually related to the CF - who then later donate the finished products to the CF. The relationship with citizens who 'only' submit material is one-sided in that they follow the call of the CF, but do not receive any reciprocal benefits (mask) to meet their own mask needs. Mutual relationships - according to the online self-presentation of the CF - exist with citizens who are able to sew and local institutions and professional groups in defined fields of action. The former receive material from the CF and can submit finished products to the $\mathrm{CF}$, and the latter can register requests with the $\mathrm{CF}$ and, depending on availability, receive masks. In this regard, the self-image as a platform is primarily limited to the function of delivering material and finished products manufactured by engaged citizens to institutions and professional groups that register for masks beforehand. 
Figure 5: The Community Foundation Gutersloh's ego-centered network

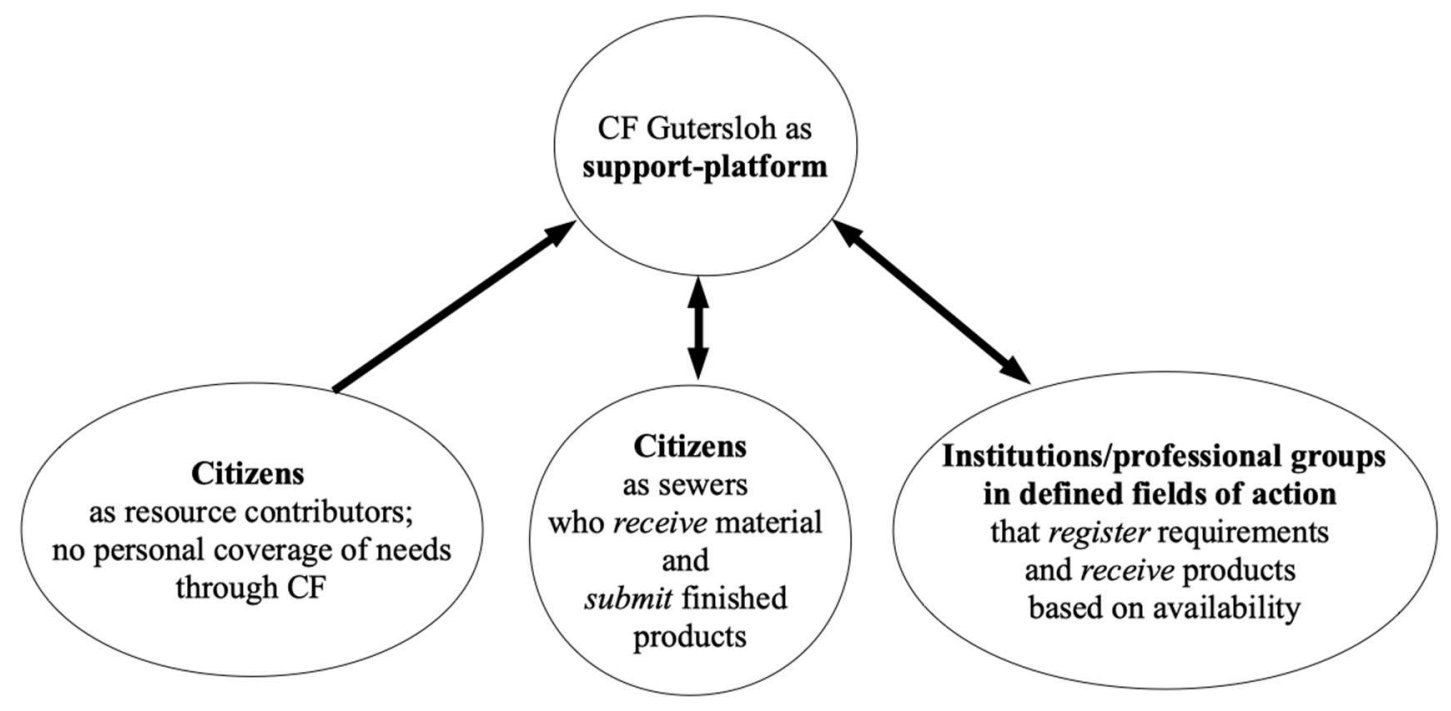

Source: own elaboration.

(3) The Community Foundation Jena can be understood as a coordinator between engaged, sewing citizens, seven local civil society organizations (known as "distribution points") and the local mayors in surrounding towns who serve the needs of citizens and organizations according to makeshift masks. It is reciprocally related to the distribution points with the exception of the citizens who follow the call of the CF and submit finished products but do not receive a service in the sense of reciprocity. In this regard, an open question to be researched would be what forms of recognition or appreciation citizens who sew and/or contribute material have received from the CFs in order to define the one-sided relationship here as reciprocal. The CF follows the appeal that comes from political decision-makers in the municipality, which is primarily aimed at the citizens themselves. Under the motto "citizens sewing for citizens", all citizens in Jena are asked to meet their own needs for makeshift masks on their own accord or to help others as volunteer sewers. The CF is also visible to other local actors in its capacity as a coordinator to meet the need for makeshift masks. The University of Jena, for example, provides information about the CF's offer and refers students who do not have their own makeshift mask to the local CF (see the university's FAQ):

"In addition to hand-sewn face masks, scarves, shawls, buffs and fabric cuts from bed sheets or other densely woven cotton fabrics (washable at $90^{\circ} \mathrm{C}$ ) are also an option. If you are not able to sew, you can get a mask from the Community Foundation Jena [...]." (Friedrich-Schiller-Universität Jena, 2020) 
Figure 6: The Community Foundation Jena's ego-centered network

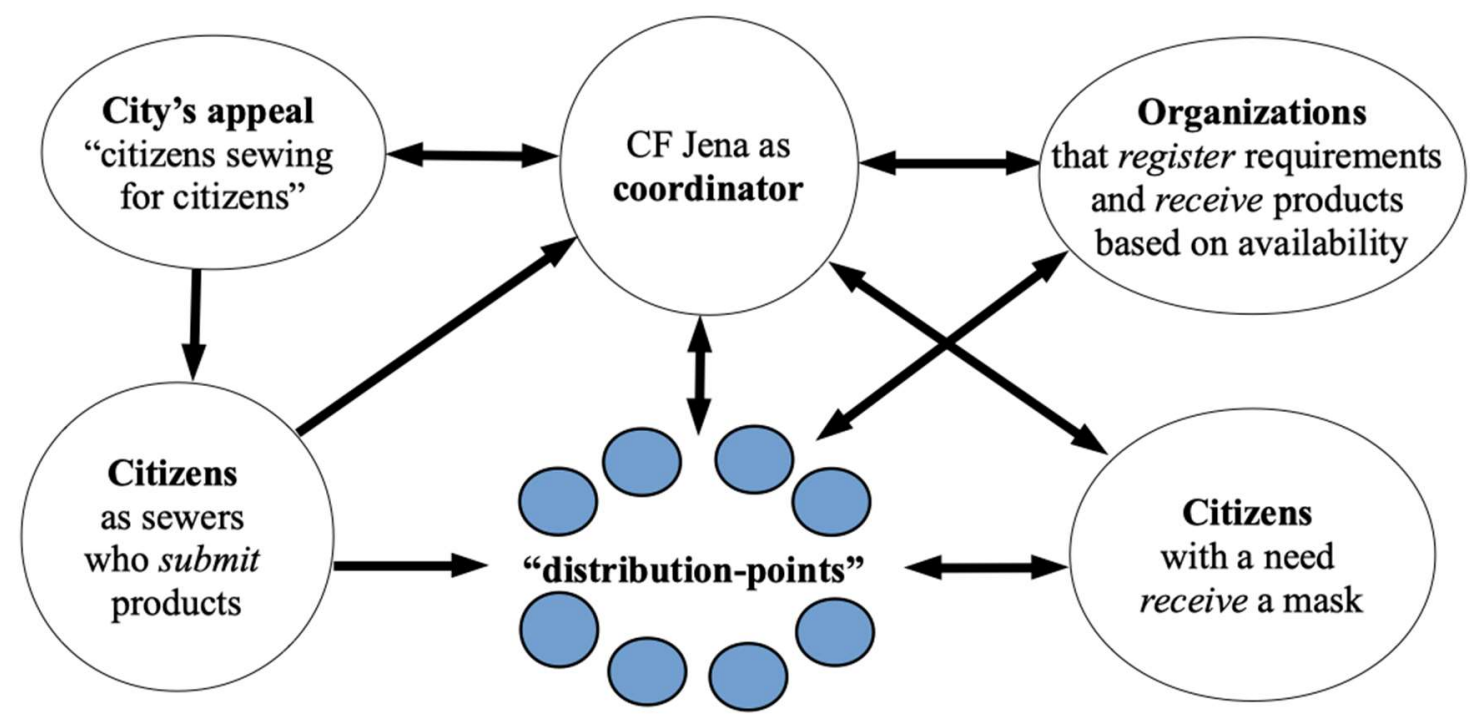

Source: own elaboration.

Overall, by comparing the network structures that serve the local need for makeshift masks for personal or professional use as registered with the CF, it becomes apparent that the CFs, in addition to their operational, charitable and supportive function (for foundations in general see: Strachwitz, 2019, 104) perform a local network function. Depending on how the CFs see and present themselves, they perform the network function in their capacity of forwarding, cooperating or coordinating actors. The CFs compensate for the shortcoming of state and market sectors in terms of fulfilling the public's need for makeshift masks. Based on the findings, it can be discussed to what extent the political/public sector fulfill the guarantee function assigned to them in the activating welfare state for goods of public interest. The "new division of responsibility" (Braun et al., 2013, 49) for the production of goods of public interest is shown in the cases analyzed as follows: It is a onesided shift of responsibility for the procurement (including the financing) and the provision of the goods on the side of the engaged and the actors of organized civil society who follow the appeals of the political decision-makers, meaning they are activated to sew and donate in the interests of the 'common good'. To put it in more drastic terms: The division of responsibility shows itself "through a policy of omission that activates citizens to independently close the emerging gaps in infrastructure and services of general interest" (van Dyk \& Haubner, 2019, 269; emphasis by the author). This omission is certainly related to the fact that the political decision-makers cannot develop or offer a solution for the procurement of the masks, but rather shift finding solutions to other (private and organized civil society) actors. At the same time, it can be stated that the CFs are able to develop and offer a solution precisely because they are locally networked and, above all, visible to donors and organizations in need. This goes hand in hand with the fact that their visibility for citizens (as volunteers or people in need) and other interest groups (organized civil society, politics and administration) influences the flow of resources and the recruiting of cooperation partners and 'multipliers' who promote the project ideas of the CFs. As a result, the practice of solidarity - sewing and donating for others in order to enable health protection - expresses the civil side of organized civil society. From a normative point of view, other self-organized formations in Germany that have emerged during the pandemic, such as the movement whose actors call themselves 'lateral thinkers', cannot be included in the sphere of civil society because they endanger the health of others, preferring to claim their individual right to freedom. With their objectives and actions, they identify themselves as uncivil "and thus not non-violent and willing to compromise" (Freise \& Zimmer, 2019, 9). 
Although Freise and Zimmer $(2019,9)$ name other formations, the aspect that these formations can be viewed as uncivil can be transferred to the aforementioned. This formation can be viewed as uncivil because the majority of its actors demonstrate without complying with the hygiene rules (socially distancing, hand washing and wearing masks), disregarding the need to protect other people from virus transmission. Considering that social distancing is a suitable means to protect other people from transmission, wearing a mask appears to be a compromise in order to be able to meet people when social distancing is not possible.

\section{Conclusion}

In summary, the following answers the main question regarding how community foundations, as local actors in organized civil society, manage the production and provision of makeshift masks and in this context take responsibility for the procurement of a good of public interest:

In times of ad-hoc political decisions that affect the local community, these actors show they are multi-talents: reactive and capable of acting, locally visible to other actors and engaged people, and in their engagement-promoting and coordinating function as reliable, networked and indispensable. By fulfilling a network function in various ways based on local conditions (cooperation, forwarding resources and coordination), it is possible for them to fulfil the needs perceived as urgent, which cannot be met by the state, nor by the private-economic sector, the private-economic sector can only meet the need to the extent that its actors change their produced goods and the customers with mask needs are able to pay market prices. The fulfillment of the network function is based on the bundling of resources provided by citizens on the basis of voluntary and gratuitous engagement as a practice of solidarity. In this article one can speak of solidarity as a self-obligation by citizens to mutual support. The recipients of the support are in particular institutions, that provide socially relevant services (in the care and social sector as well as in schools). The fulfillment of their need for masks was and is necessary so that they can also carry out their tasks.

With the mobilization of engaged people for the production of the scarce good makeshift mask, CFs can also be ascribed market relevance since they distribute products with a corresponding market value due to their high demand to organizations and citizens. Even though civil society organizations are not geared towards maximizing their financial profits with their range of services (and here the mediated products), the consideration of the network function shows that there are both financially relevant and non-monetary profits for the participants. In financial terms, the voluntary practice of solidarity by engaged citizens, who bring in their resources to meet the needs of community actors is a benefit for those in need of a mask. Finally, this practice of solidarity enables those who receive a mask to save the real market value and to be relieved of having to pay the real market value at all. In non-monetary terms, the practice of solidarity based on the engagement of citizens proves to be a gain in legitimacy for the organizations, which can only result through this practice itself. Without following the appeals and calls by engaged citizens who show solidarity and/or cooperative actors on site (such as project partners) as well as their practical engagement, the calls would go unheard and the projects would be ineffective at the operational level. Solidarity as a basis for action is fragile, however, because it originates from the active engagement of citizens, which is (also) based on self-obligation for the good of others and the expectations of reciprocity. Organized civil society actors are challenged in the pandemic in several ways: They operate in the area of tension between being commissioned by political actors who delegate responsibility and the need to gain legitimacy by presenting themselves as independent of both the state and the market in order to gain the trust of those who donate resources. And they are called upon to 
defend their civil side discursively and produce it in the form of practices of solidarity in order to oppose the uncivilized formations in society.

Looking ahead, a future empirical study could investigate: (1) to what extent the spontaneous reactions of civil society organizations, which have led to the development of networks to meet an urgent need, will be transferred into sustainable structures that are supported by local engagement policy or by local politicians in the sense of fulfilling a guarantee function and therefore assuming the responsibility for ensuring "that there are corresponding goods and services for all citizens in a certain quality and quantity" (Nullmeier, 2011, 292). After all, engagement policy in particular is an issue that depends on the creative will of the political decision-makers. In this context, an offline focus could be used to investigate the local framework conditions in the context of which the CFs (and other local organized civil society actors) could continue their network function in the sense of sustainable engagement-promotion. (2) Regarding reciprocity as it concerns the organizations and the people who donate resources, an offline focus would have to be used to examine the mutual relationships in order to determine which expectations were fulfilled, meaning which forms of recognition and appreciation were shown by the CFs in connection with the engagement that is limited in terms of time and purpose.

\section{References}

Albrecht, S. (2010). Knoten im Netzwerk. In C. Stegbauer \& R. Häußling (Eds.): Handbuch Netzwerkforschung (125-134). Wiesbaden: VS Verlag für Sozialwissenschaften.

Backhaus-Maul, H. (2019). Zentrifugalkräfte in der Freien Wohlfahrtspflege: Wohlfahrtsverbände als traditionsreiche und ressourcenstarke Akteure. In M. Freise \& A. Zimmer (Eds.). Zivilgesellschaft und Wohlfahrtsstaat im Wandel. Bürgergesellschaft und Demokratie (83-100). Wiesbaden: Springer Fachmedien.

Backhaus-Maul, H. \& Hörnlein, M. (2014). Vorstellungswelten und SteuerungsversucheEngagement in der verbandlichen Wohlfahrtspflege. In A. E. Zimmer \& R. Simsa (Eds.). Forschung zu Zivilgesellschaft, NPOs und Engagement (115-131). Wiesbaden: Springer Fachmedien.

Backhaus-Maul, H., Speck, K., Hörnlein, M. \& Krohn, M. (2015). Engagement in der Freien Wohlfahrtspflege: Empirische Befunde aus der Terra incognita eines Spitzenverbandes. Wiesbaden: Springer VS.

Bozdağ, Ç. (2018). Theoretisches Sampling von Online-Inhalten. In C. Pentzold, A. Bischof, \& N. Heise (Eds.). Praxis Grounded Theory (131-148). Wiesbaden: Springer Fachmedien.

Braun, S., Hansen, S. \& Langner, R. (2013). Bürgerschaftliches Engagement an Schulen. Wiesbaden: Springer Fachmedien Wiesbaden.

Bürgerstiftung Braunschweig (2020a). Verkauf von Behelfsmasken an Privatpersonen. Retrieved from: https://www.buergerstiftungbraunschweig.de/infos/aktuelles/artikel/ verkauf-von-behelfsmasken-an-privatpersonen/. Accessed 08 May 2020. 
Bürgerstiftung Braunschweig (2020b). Behelfs-Mund-Nasenmasken: Projekt endet. Retrieved from: https://www.buergerstiftungbraunschweig.de/projekte/projekt/?tx_bsdv_ projekte\%5Baction\%5D=show\&tx_bsdv_projekte\%5Bcontroller\%5D=Projekt\&tx_ bsdv_projekte\%5Bprojekt\%5D=2\&cHash=4a065cc3be347a21bf0bd5ffb4b4d451. Accessed 08 May 2020.

Bürgerstiftung Braunschweig (2020c). Verkauf von Behelfsmasken an Privatpersonen. Retrieved from: https://www.buergerstiftungbraunschweig.de/infos/aktuelles/artikel/ verkauf-von-behelfsmasken-an-privatpersonen/ Accessed 08 May 2020.

Bürgerstiftung Gütersloh (2020). Maske auf! Retrieved from: https://www.buergerstiftung-guetersloh.de/informieren/projekte/detail/article/216-maske-auf/?L=0\&cHash= f5a0a2c86807b05ad334c8168e0c8b1a Accessed 14 May 2020.

Bürgerstiftung Jena (2020). Nähen für Jena. Retrieved from: https://www.buergerstiftungjena.de/hilfe-in-der-corona-krise.html Accessed 07 May 2020.

Clemens, I. (2016). Netzwerktheorie und Erziehungswissenschaft: eine Einführung. Weinheim Basel: Beltz Juventa.

Dein Guethersloh (2020). 1.000 Masken für Gütersloh. „Maske auf - Nähen für Gütersloh“. Retrieved from: https://www.dein-guetersloh.de/news/allgemeines/1000-masken-fuerguetersloh Accessed 16 May 2020.

Evers, A. (2020). Die Zivilgesellschaft und ihre Organisationen. Ein Vergleich verschiedener Ansätze. In A. Schröer, N. Engel, C. Fahrenwald, M. Göhlich, C. Schröder, \& S. M. Weber (Eds.). Organisation und Zivilgesellschaft. Organisation und Pädagogik (9-32). Wiesbaden: Springer Fachmedien.

Evers, A. \& Olk, T. (1996). Wohlfahrtspluralismus - Analytische und normativ-politische Dimensionen eines Leitbegriffs. In A. Evers \& T. Olk (Eds.). Wohlfahrtspluralismus. Vom Wohlfahrtsstaat zur Wohlfahrtsgesellschaft (9-60). Opladen: Westdeutscher Verlag.

Freise, M. \& Zimmer, A. (2019). Zivilgesellschaft und Wohlfahrtsstaat in Deutschland: Eine Einführung. In. M. Freise \& A. Zimmer (Eds.). Zivilgesellschaft und Wohlfahrtsstaat im Wandel. Bürgergesellschaft und Demokratie (3-22). Wiesbaden: Springer Fachmedien.

Friedrich-Schiller-Universität Jena (2020). Corona-Informationen. Die aktuelle Lage an der Universität. Retrieved from: https://www.uni-jena.de/200407_Corona_Informationen Accessed 07 May 2020.

Fuhse, J. (2018). Soziale Netzwerke: Konzepte und Forschungsmethoden. Konstanz: UVK.

Geimer, A. (2018). Onlineforschung. In R. Bohnsack, A. Geimer \& M. Meuser (Eds.): Hauptbegriffe Qualitativer Sozialforschung. (175-179). Opladen und Toronto: Verlag Barbara Budrich.

Hollstein, B. (2006). Qualitative Methoden und Netzwerkanalyse - ein Widerspruch? In B. Hollstein \& F. Straus (Eds.). Qualitative Netzwerkanalyse. Konzepte, Methoden, Anwendungen (11-35). Wiesbaden: VS Verlag für Sozialwissenschaften. 
Huxhold, O. \& Müller, D. (2017). Werthaltungen und freiwilliges Engagement. In. J. Simonson, C. Vogel, \& C. Tesch-Römer (Eds.). Freiwilliges Engagement in Deutschland (485-498). Wiesbaden: Springer Fachmedien Wiesbaden.

Jahberg, H. (2020). So kommen Sie doch noch an Atemschutzmasken. Retrieved from: https://www.tagesspiegel.de/wirtschaft/mundschutz-kaufen-so-kommen-sie-doch-nochan-atemschutzmasken/25740212.html Accessed 28 April 2020.

Jakob, G. (2010). Infrastrukturen und Anlaufstellen zur Engagementförderung in den Kommunen. In T. Olk, A. Klein \& B. Hartnuß (Eds.). Engagementpolitik. Die Entwicklung der Zivilgesellschaft als politische Aufgabe (233-259). Wiesbaden: VS Verlag für Sozialwissenschaften.

Janowitz, K. M. (2009). Netnographie - Ethnographische Methoden im Internet und posttraditionelle Vergemeinschaftungen. In P. Ohly (Ed.). Tagungsband zur Wissensorganisation '09 „Wissen - Wissenschaft - Organisation“ (1-9), 12. Tagung der Deutschen ISKO International Society for Knowledge Organization, 19. - 21.10.2009, Bonn.

Jansen, D. (1999). Einführung in die Netzwerkanalyse: Grundlagen, Methoden, Anwendungen. Wiesbaden: Springer Fachmedien.

Kocka, J. (2003). Zivilgesellschaft in historischer Perspektive. Forschungsjournal Neue Soziale Bewegungen 16(2), 29-37.

Kuckartz, U. (2016). Qualitative Inhaltsanalyse. Methoden, Praxis, Computerunterstützung. 3., überarbeitete Auflage Weinheim und Basel: Beltz Juventa.

Kühl, S. (2011). Organisationen. Wiesbaden: VS Verlag für Sozialwissenschaften.

Kuhnt, J. (2018). Engagementförderung zwischen Professionalisierung, Deprofessionalisierung und Selbstoptimierung. neue praxis: Zeitschrift für Sozialarbeit, Sozialpädagogik und Sozialpolitik 48(6), 547-570.

Kuhnt, J. (2019). The dynamics of local responsibility sharing: Engagement-promoting organizations and structures in Germany. Voluntaris 7(2), 151-177.

Kuhnt, J. (2020). A story about storytellers - Innovationspotenziale in Bürger*innenstiftungen und Freiwilligenagenturen. In H.-W- Franz, G. Beck, D. Compagna, P. Dürr, W. Gehra \& M. Wegner (Eds.). Nachhaltig Leben und Wirtschaften. Sozialwissenschaften und Berufspraxis (321-345). Wiesbaden: Springer Fachmedien.

Müller, D., N. Hameister \& K. Lux (2017). Anstoß und Motive für das freiwillige Engagement. In. J. Simonson, C. Vogel \& C. Tesch-Römer (Eds.): Freiwilliges Engagement in Deutschland (413-435). Wiesbaden: Springer Fachmedien.

Nullmeier, F. (2011). Governance sozialer Dienste. In. A. Evers, R. G. Heinze \& T. Olk (Eds.): Handbuch Soziale Dienste (284-298). Wiesbaden: VS Verlag für Sozialwissenschaften.

Przyborski, A. \& Wohlrab-Sahr, M. (2014). Qualitative Sozialforschung: Ein Arbeitsbuch. München: Oldenbourg Verlag. 
Robert Koch Institut (2020). Ist das Tragen einer Mund-Nasen-Bedeckung in der Öffentlichkeit zum Schutz vor SARS-CoV-2 sinnvoll? Retrieved from: https://www.rki.de/ SharedDocs/FAQ/NCOV2019/FAQ_Mund_Nasen_Schutz.html Accessed 12 May 2020.

Schnabel, S. (2020). Masken: Was sie kosten dürfen und wo es sie gibt. Retrieved from: https://www1.wdr.de/nachrichten/themen/coronavirus/wo-kann-man-masken-kaufen100.html Accessed 12 May 2020.

Simonson, J. \& Vogel, C. (2017). Organisationale Struktur des freiwilligen Engagements und Verbesserungsmöglichkeiten der Rahmenbedingungen. In. J. Simonson, C. Vogel, \& C. Tesch-Römer (Eds.): Freiwilliges Engagement in Deutschland (523-548). Wiesbaden: Springer Fachmedien Wiesbaden.

Speck, K., Backhaus-Maul, H., Friedrich, P. \& Krohn, M. (2012). Freiwilligenagenturen in Deutschland. Wiesbaden: VS Verlag für Sozialwissenschaften.

Stadt Jena (2020). Coronavirus. Retrieved from: https://gesundheit.jena.de/de/coronavirus Accessed 11 May 2020.

Strachwitz, R. (2019). Stiftungen und Wohlfahrtsstaat. In M. Freise \& A. Zimmer (Eds.). Zivilgesellschaft und Wohlfahrtsstaat im Wandel. Bürgergesellschaft und Demokratie (101122). Wiesbaden: Springer Fachmedien.

Technische Universität Braunschweig (2020). behelfs.mundschutz.fuer.braunschweig. Retrieved from: https://www.sandkasten.tu-braunschweig.de/projekte/mundschutznaehen-fuer-medizinische-einrichtungen. Accessed 08 May 2020.

van Dyk, S. \& Haubner, T. (2019). Gemeinschaft als Ressource? Engagement und Freiwilligenarbeit im Strukturwandel des Wohlfahrtsstaats. In. A. D. Baumgartner \& B. Fux (Eds.): Sozialstaat unter Zugzwang? (259-279). Wiesbaden: Springer Fachmedien.

Walgenbach, P. \& Meyer, R. (2008). Neoinstitutionalistische Organisationstheorie. Stuttgart: Kohlhammer W., GmbH.

Wolf, A. C. \& Zimmer, A. (2012). Lokale Engagementförderung. Wiesbaden: VS Verlag für Sozialwissenschaften.

Zimmer, A. (2019). Wohlfahrtsstaatlichkeit in Deutschland: Tradition und Wandel der Zusammenarbeit mit zivilgesellschaftlichen Organisationen. In. M. Freise \& A. Zimmer (Eds.). Zivilgesellschaft und Wohlfahrtsstaat im Wandel. Bürgergesellschaft und Demokratie (2354). Wiesbaden: Springer Fachmedien.

Zimmer, A. \& Priller, E. (2007). Gemeinnützige Organisationen im gesellschaftlichen Wandel: Ergebnisse der Dritte-Sektor-Forschung. Wiesbaden: VS Verlag für Sozialwissenschaften. 